\title{
Governance and civil and political rights as FDI determinants in transition countries, ${ }^{*}$
}

\author{
Jelena Zvezdanović Lobanova ${ }^{2}$, Mikhail Lobanov ${ }^{3}$, \\ Milan Zvezdanovic ${ }^{4}$
}

\begin{abstract}
This paper aimed to investigate the FDI determinants in 27 transition countries within the $2002-2018$ period by employing system GMM analysis. One of the results of our research is that an uncertain political situation and civil liberties violations have a significant negative impact on foreign investors' confidence. Generally, the erosion of democratic institutions acts as a deterrent to FDI inflows. Transition countries which experienced prolonged periods of central planning also recorded lower levels of FDI inflows. The results show that creating conditions for stimulating foreign investors through the improvement of institutional quality embodied in the control of corruption and voice and accountability impacted positively on FDI inflows. The interplays between overall institutional quality, voice and accountability, regulatory quality, government effectiveness and GDP growth are positive and significant. Hence, macroeconomic development has an important impact on the marginal effect of institutional quality. Therefore, we
\end{abstract}

* Received: 10-01-2021; accepted: 22-06-2021

1 The paper was written within the research programme of the Institute of Social Sciences for 2021 supported by Ministry of Education, Science and Technological Development of the Republic of Serbia.

2 Research Associate, Center for Economic Research, Institute of Social Sciences, Kraljice Natalije 45, 11000 Belgrade, Serbia. Scientific affiliation: international capital flows, crossborder mergers and acquisitions, and quality of institutional setting. Phone: +381113616002 . E-mail: jzvezdanovic@idn.org.rs.

3 Deputy Director for Research, Senior research fellow, Institute of Economics, Russian Academy of Sciences, Nakhimovskiy pr. 32, 117997 Moscow, Russian Federation. Scientific affiliation: problems of socio-economic and political development of Central-Eastern and South-Eastern Europe, the EU enlargement, functional and territorial organization of industry and agriculture and varieties of capitalist relations.Phone:+74997241541.E-mail:m.m.lobanov@yandex.ru.

4 Docent, Academy for National Security, Kraljice Ane bb, 11000 Belgrade, Serbia. Scientific affiliation: mergers and acquisitions, corporative management, corruption and institutional development. Phone: +381648495255.E-mail: zvezdanovicmilan@gmail.com. 


\begin{abstract}
concluded that the influence of governance on FDI inflows is conditional on the transition countries' macroeconomic performance. Our findings also reveal that of the governance dimensions, control of corruption and voice and accountability have a significant influence on the decision of multinationals to undertake investment.
\end{abstract}

Key words: foreign direct investment, institutions, civil society, democracy, transition countries

JEL classification: D73, E22, F21, F23, O52

\title{
1. Introduction
}

The issue of cross-border capital flows is one of the key areas in the study of foreign economic activity at the national and corporate levels. The territorial and sectoral structure transformation of cross-border investment flows, and their dynamics have enabled us to assess the international division of labour development in the modern globalizing world. Studies on international investment activity are highly controversial and leave open unanswered questions about the advantages and disadvantages of capital attraction, factors concerning the investment competitiveness of recipient countries, the effects of capital exports in home countries, and, finally, the essential reasons for the movement and accumulation of capital. The transition countries considered in this paper have only been actively involved in the global process of capital redistribution for a few decades, but their experience in participating in cross-border investment flows is very revealing and has been the subject of an extensive number of scientific studies. Of particular interest in this regard is the issue of institutional factors in attracting foreign direct investment (FDI), which are usually addressed less frequently than macroeconomic factors.

Analysis of cross-border capital movements shows that FDI inflows in transition countries are linked to progress in the implementation of economic reforms. It is believed that some transition countries have attracted fewer capital flows than expected due to factors like the quality of the institutional environment, macroeconomic instability, differences in technology, high adjustment costs, etc. (Lipschitz et al., 2001). Some studies have proved that the improvement of the institutional framework together with the abolition of capital restrictions and the enhancement of economic growth influence patterns of international capital flows. The characteristics of institutional development in the host transition countries determine the investment decisions of transnational companies (TNCs) as regards entry mode strategy (Dikova and Witteloostuijn, 2007).

Although, in general, openness to capital flows influenced economic modernization, in most industries the expected technology transfer did not happen. It was primarily because TNC subsidiaries only insignificantly integrated local firms into their 
global and regional value chains. According to some studies, FDI does not generate positive intra-industry spillovers for domestic firms in transition countries (Damijan et al., 2003). Intersectoral and intrasectoral spillover effects affecting productivity and technology transfer have arisen in only a few transition countries, characterized by a developed institutional environment.

FDI inflows in these countries are often attracted by different types of incentives which play a role of compensation for an underdeveloped business environment and potential macroeconomic risks. These incentives are also often caused by mutual competition between countries of the region characterized by similar macroeconomic conditions. The incentives to foreign investors are usually various subsidies and tax breaks. In addition, the key drivers for FDI attraction in these countries are natural resources, the availability of cheap, unskilled or semi-skilled labour, adequate technological capacity, and management skills of the host country (Dunning and Lundan, 2008).

This paper aims to provide a broader perspective on FDI determinants in transition countries. We analyze the influence of governance and democratic society variables on FDI inflows in 27 transition countries from 2002 to 2018 by using dynamic panel data approach. ${ }^{5}$ In addition, we examine the possibility of whether the marginal impact of various governance dimensions on FDI inflows is determined by the economic conditions in transition countries. We will not only assess the marginal effect of the overall Worldwide Governance Indicators (WGIs), but also examine the impact of six governance indicators on FDI inflows according to separate models. Based on the previous empirical findings, we build three hypotheses. The first hypothesis is as follows: respect for political rights and civil liberties bears testament to a movement towards democracy and could lead to an increase in FDI inflows into host transition countries. The second hypothesis is formulated as: an improvement in governance has positive and significant effect on FDI attraction in transition countries. Finally, we assume that the creation of conditions for stimulating foreign investors through the improvement of institutional quality combined with favourable macroeconomic development influence positively on FDI inflows. The results of this research will broaden our understanding of the interdependence of governance and democratic society institutions and macroeconomic development on FDI inflows in transition countries.

\footnotetext{
5 Countries included in the sample: Albania, Armenia, Azerbaijan, Belarus, Bosnia and Herzegovina, Bulgaria, Croatia, Czech Republic, Estonia, Georgia, Hungary, Kazakhstan, Kyrgyz Republic, Latvia, Lithuania, Moldova, Montenegro, North Macedonia, Poland, Romania, the Russian Federation, Serbia, Slovakia, Slovenia, Tajikistan, Ukraine and Uzbekistan. Taking into account the time period of the study (starting from 2002), we deliberately included in the sample those countries that became members of the European Union in 2004, 2007, and 2013, i.e. formally lost the status of countries with economies in transition.
} 
This paper is structured as follows: first, we review the literature concerning the determinants of FDI inflows, the following sections present our methodology, model specification and data, and the final one discusses the results.

\section{Literature review}

The second half of the 20th century marked the FDI's steady growth in different political and socio-economic conditions. It increased research activities focused on the investment decisions of companies. However, the fact remains that, despite the vast number of theoretical and empirical studies on FDI, they have not yielded a consensus. Empirical studies on FDI determinants are substantial, but there is no consensus on the role of factors influencing investors' behaviour. Several recent studies have confirmed that low transaction and labour costs, the availability of natural resources, geographical position, market size, access to infrastructure, the degree of openness could influence decisions on the location of FDI (Demirhan and Masca, 2008; Chanegriha et al., 2017; Asongu et al., 2018). Most of them are within the well-known Dunning's eclectic paradigm methodological frames (Dunning, 2000). However, some authors pinpoint that for multinational companies, efficiency-seeking factors such as the level of the minimum wage, the unemployment rate, or corporate income taxation in host countries, are not relevant factors (see Wach and Wojciechowski, 2016). They believe that increasing the degree of investor protection and labour productivity could attract additional levels of FDI.Shukurov (2016) used a panel of CIS countries and found that foreign investors are more sensitive to various factors such as market size, abundance in natural resources, FDI stock, fiscal imbalance and inflation. He indicates that these determinants influence the pattern of FDI inflows in transition countries regardless of the presence of high investment risk. On the other hand, Ezeoha and Cattaneo (2012) note that urban infrastructure, property rights policy, trade openness and institutional quality (rule of law) can significantly affect FDI, especially in nonresource-rich countries, while Bobenič Hintošova et al. (2018) suggest the level of gross wages and the share of educated labour force have the greatest positive influence on foreign investor attraction. The latter paper also reveals that factors such as corporate income tax, trade openness and expenditure on research and development deter FDI inflows in Visegrad countries.

In recent years, a growing number of authors have emphasized the importance of institutional setting as a determinant of FDI inflows (Fabry and Zeghni, 2010; Kazemi and Azman-Saini, 2017; Azis, 2018; Mahmood et al., 2019). For example, Bevan et al. (2004) examined the relationship between various dimensions of a newly-created institutional framework in East European transition economies and FDI inflows. They found that the quality of formal institutions (especially the private ownership of business, banking sector reform, foreign exchange, trade 
liberalization, and legal developments) had encouraged FDI inflows in transition economies. FDI sensitivity to the institutional environment was also shown in a paper by Fabry and Zeghni (2006). The authors argue that foreign investors are more willing to invest in new EU members than in post-socialist countries which have become or are on the way to becoming candidates for EU membership. The institutional arrangement in countries which have already fulfilled the acquis communautaire requirements is characterized by greater stability and reliability, positively impacting on the level of inward FDI. Moreover, expectations of accession to the EU lead to large-scale financial inflows, in particular FDI.

Researchers tend to differentiate between institutional factors for attracting FDI based on the level of socio-economic and political development of countries. For instance, Peres et al. (2018) provide evidence that the quality of institutions has a positive and significant impact on FDI in developed countries, while their influence in developing countries has not been identified. Similarly, Sabir et al. (2019) show that institutional setting has a more significant impact on FDI inflows in developed countries than in developing ones. The authors also reveal that factors such as GDP per capita, agriculture value-added and a high inflation rate tend to discourage foreign investors in developed countries. In the case of developing countries, the authors point out that GDP per capita, trade openness, agriculture value-added and infrastructure play an important role in attracting FDI inflows, while, by observing advanced economies, Dellis et al. (2017) also provide evidence that quality of economic structure and institutions are influential factors in this, too. They argue that foreign investors are not only interested in respect for basic rights (rule of law, property rights or regulatory efficiency), but also the well-functioning of labour markets and product markets in host countries. The results mentioned above are in contrast to the findings of Jadhav (2012), who investigated the role of economic, institutional and political determinants of FDI in BRICS countries. He demonstrates that economic factors such as market size measured according to real GDP, trade openness and natural resource availability are more important to foreign investors than institutional and political factors.

On the other hand, Lucke and Eicher (2016) point out that FDI is affected by improvements in institutional quality in developing and transitional economies more than in developed countries. They provide evidence that foreign investors are likely to invest in developed countries characterized by a higher level of corruption and a politically unstable system (compared to their home countries). Younsi and Bechtini (2019) found that political stability, government effectiveness and regulatory quality are the main drivers of FDI inflows in emerging host countries. Therefore, they stress the importance of sound economic policies and the implementation of regulations to improve the investment climate. Lacroix et al. (2018) demonstrate that low political risk and democratic institutions are important for attracting FDI in developing countries. The authors emphasise that consolidated 
democratic transitions defined as those that do not go into reverse for at least five years bring in a higher amount of FDI.

These results contrary to the findings of Adam and Filippaios (2007). They demonstrate that multinational firms tend to invest in countries characterized by low civil liberties but high political rights. They stress that such a result can be explained by the various motives of foreign investors in different types of countries. A study by Asiedu and Lien (2011) reveals interesting results regarding the relationship between democracy and FDI inflows in a large number of developing countries. The authors demonstrate that democracy promotes FDI only if the share of mineral resources in total exports is lower than a certain critical value and they show that the expansion of democracy enhanced FDI in 90 countries while in the remaining countries it was a deterrent.

The recent empirical study by Economou (2019) shows that economic freedom components such as protection of property rights, monetary and financial freedom, government integrity bear positive impact on FDI inflows in four South European economies. Paul and Jadhav (2020) argue that institutional setting measured by effective rule of law, political stability, regulatory quality and control on corruption has significant impact on FDI in emerging markets, as well as infrastructure quality and trade cost measured by tariff and non-tariff barriers. By investigating the effects of traditional, institutional and agglomeration determinants on choice of investment location on a sample of six countries of the Western Balkans, Kurtovic et al. (2020) highlight that traditional (GDP per capita and GDP growth rate), agglomeration (urbanisation rate, foreign agglomerations in the service sector and the number of employees in the service sector) and institutional determinants (government spending) have a positive impact on the choice of FDI location.

\section{Research methodology}

To assess the FDI determinants, a number of researchers apply the dynamic panel data analysis, primarily because of providing an overview of the spatial and temporal dimensions for all units in the sample. System GMM estimator allows us to model the dynamic aspects of the FDI inflows and take into account the endogenous nature of explanatory variables included in our analysis. This estimator is suitable for panel data analysis characterized by small $\mathrm{T}$ and large $\mathrm{N}$ and for models with endogenous and predetermined explanatory variables. It checks for the presence of unobserved country-specific effects, as well as for a simultaneity bias caused by the potential endogeneity of the explanatory variables. Thanks to dynamic panel data analysis, we were able to investigate the dynamics of adjustment by including a lagged endogenous variable among the exogenous variables and to address the problems of potential endogeneity, autocorrelation and 
heteroscedasticity in our models. Namely, the system GMM estimator enabled us to see the effects of lagged FDI on the current inflows.

System GMM involves combining moment conditions for the model in first differences with moment conditions for the model in levels (Bun and Windmeijer, 2010). This estimator has an advantage over Difference GMM in cases when randomwalk variables (or those close to being random-walk variables) and time-invariant variables (such as the number of years under central planning in our case) are included in the analysis. In addition, as highlighted by Roodman (2009), this estimator can significantly improve efficiency and concurrently allows for more instruments.

It was used to overcome the shortcomings of its difference-based GMM counterparts, which occur in cases when the series are highly persistent (Blundell and Bond, 1998). This estimator is commonly used in studies that investigate the importance of institutional quality, whose variables are characterized by long-term persistence. In such circumstances, the system GMM estimator helps us to reduce biased parameter estimates and the imprecision associated with other methods (Blundell et al. 2000).

Following Kucera and Principi (2017) Lucke and Eichler (2016), Sabir et al. (2019), we used a dynamic system Generalized Method of Moment (GMM) estimator on a panel data set compiled from annual observations of 27 transition countries. This model examines the determinants of FDI inflows in chosen set of countries:

$$
\begin{aligned}
& \mathrm{FDI}_{\mathrm{it}}=\beta_{0}+\beta_{1} \mathrm{FDI}_{\mathrm{it}-1}+\beta_{2} \mathrm{GDPG}_{\mathrm{it}}+\beta_{3} \mathrm{OPEN}_{\mathrm{it}}+\beta_{4} \mathrm{GFCF}_{\mathrm{it}}+ \\
& \beta_{5} \mathrm{INF}_{\mathrm{it}}+\beta_{6} \text { DEMOCRACY }_{\mathrm{it}}+\varepsilon_{\mathrm{it}}
\end{aligned}
$$

where the subscript $i$ denotes the $i^{\text {th }}$ country $(i=1 \ldots 27)$ and the subscript $t$ denotes the $\mathrm{t}^{\text {th }}$ year $(\mathrm{t}=1 \ldots 17)$, while $\beta_{0}$ to $\beta_{6}$ are regression coefficients and $\varepsilon_{\mathrm{it}}$ are the error terms. FDI is FDI inflows as a percentage of GDP, FDI $\mathrm{it}_{\mathrm{it}-1}$ is the lagged dependent variable, GDPG is GDP growth as a measure of macroeconomic development, OPEN is Trade as a percentage of GDP as a measure of trade restriction, GFCF is gross fixed capital formation as a percentage of GDP as a measure of infrastructure development, INF is the average consumer price (percentage change) as a measure of macroeconomic stability, and DEMOCRACY is a vector of determinants like:

- political rights (POLRIGHTS);

- civil liberties (CIVLIBERTIES), and

- a dummy variable for STATUS.

The impact of governance indicators and their interplay with macroeconomic development was also investigated with the following panel model specifications: 


$$
\begin{aligned}
& \mathrm{FDI}_{\mathrm{it}}=\beta_{0}+\beta_{1} \mathrm{FDI}_{\mathrm{it}-1}+\beta_{2} \mathrm{GDPG}_{\mathrm{it}}+\beta_{3} \mathrm{OPEN}_{\mathrm{it}}+\beta_{4} \mathrm{GFCF}_{\mathrm{it}}+ \\
& \beta_{5} \mathrm{INF}_{\mathrm{it}}+\beta_{6} \mathrm{INS}_{\mathrm{it}}+\varepsilon_{\mathrm{it}} \\
& \mathrm{FDI}_{\mathrm{it}}=\beta_{0}+\beta_{1} \mathrm{FDI}_{\mathrm{it}-1}+\beta_{2} \mathrm{GDPG}_{\mathrm{it}}+\beta_{3} \mathrm{OPEN}_{\mathrm{it}}+\beta_{4} \mathrm{GFCF}_{\mathrm{it}}+ \\
& \beta_{5} \mathrm{INF}_{\mathrm{it}}+\beta_{6} \mathrm{INS}_{\mathrm{it}} * \mathrm{GDPG}_{\mathrm{it}}+\varepsilon_{\mathrm{it}}
\end{aligned}
$$

where $\mathrm{INS}_{\mathrm{it}}$ stands for the overall institutional quality index (denoted as OWGI), obtained by the Principal Component Analysis Method - PCA, as well as governance indicators, which were included separately in order to avoid multicollinearity.

PCA is used for dimension reduction within a large dataset and saving computation. Its advantage is that it keeps as much variation as possible and retains most of the information while enabling it to avoid multicollinearity. This mathematical technique summarizes the six governance indicators (Voice and Accountability (VA), Political Stability and Absence of Violence (PSAV), Government Effectiveness (GE), Regulatory Quality (RQ), Rule of Law (RL), and Control of Corruption (CC)) into one factor (OWGI). The value of each indicator ranges from -2.5 to 2.5 , with higher values indicating a better quality of the institutional setting.

The first principal component derived from these indicators can explain about $87 \%$ of the variations in the original six governance indicators. In addition, according to the Kaiser-Meyer-Olkin (KMO) measure of sampling adequacy $(0.90)$, the data is suitable for PCA. Therefore, we were able to use the first PCA component as an indicator for an assessment of the impact of institutional quality in transition countries and thus eliminate problems, which could occur due to omitted variable bias.

In model specification (2), we examined which aspects of institutional quality have contributed most to FDI inflows, while in specification (3) we assessed the combined effect on FDI inflows by employing the interaction terms between GDP growth and various governance dimensions. In our study, the lagged dependent variable, GDP growth and GFCF were treated as endogenous variables in each of our regressions. We also used lags 2 to 4 of endogenous variables in order to alleviate the instrument proliferation problem. The collapse option was also used to reduce the size of the instruments matrix. We performed the 'Windmeijer correction' (Windmeijer, 2005) using Stata's 'small' command (Roodman, 2009) to obtain corrected standard errors. We employed the Hansen test to analyse the appropriateness of the model specification and the validity of over-identifying restrictions. According to Roodman (2009), problems which occur due to instrument proliferations are overfitting of endogenous variables and failure to expunge their endogenous components. We are guided by the rule that the number 
of instruments should not exceed the number of groups in order to maintain the validity of the Hansen over-identification test to reduce bias. Moreover, Roodman (2009) suggested that the Hansen p-value should have a higher value than the 0.1, at least 0.25 levels. In addition, we also tested for second-order serial correlations AR (2) of the differenced residuals. Having in mind that lagged values are used as instruments, unbiased estimation requires the absence of second-order serial correlation in the error term (Arellano and Bond, 1991). To test this requirement, we perform the Arellano-Bond AR (2) test. A p-value of greater than 0.05 implies the absence of second-order autocorrelation. All the estimations were performed using the xtabond2 program written by Roodman (2009).

\section{Empirical data and analysis}

The choice of the time period and the set of transition countries were dependent on data availability. In our research, we tried to include variables that prove to have significant influence on FDI inflows. Some of the macroeconomic variables used in other studies were found insignificant in our calculations. A list of all the variables included in our dynamic panel data analysis is presented in Appendix. Data for our dependent variable FDI inflows as a percentage of GDP were taken from the World Bank World Development Indicators online database. The same source was used for GDP growth, Trade openness and GFCF. Data on Worldwide governance indicators were obtained from the World Bank Worldwide Governance Indicators project database and data on inflation (average consumer prices, percentage change) - from the World Economic Outlook database developed by the International Monetary Fund.

As far as the concept of institutional quality is concerned, we adhere to the description proposed by the experts of the World Bank. According to them, institutional quality is positively associated with balances in the political system and civil rights, as well as with the commitment to policy measures of openness (Islam and Montenegro, 2002). We used civil and political rights indicators by the Freedom House Foundation (Freedom in the World database), which rates all countries according to the development of their democratic institutions. Each of these two indices is given a value between 1 and 7, with 1 representing the highest degree of freedom or democratic rights and liberties and 7 the lowest. According to Freedom House, the political rights rating is constructed based on the status of the electoral process, political pluralism and participation, and the functioning of government. The civil liberties rating assesses the presence or lack of freedom of expression, associational and organizational rights, rule of law, and personal autonomy and individual rights. Transition countries are likely to be less attractive to foreign investors if they exhibit a weakening of democratic norms. Therefore, the expected signs of coefficients are negative. 
We also added a dummy variable to evaluate the impact of the state of democracy (free, partly free, or not free) on the decision of potential foreign investors. For instance, the dummy variable STATUS is given the value 1 when denoting countries that are classified as partly free or not free, and 0 otherwise (free countries). Additionally, institutional development encompasses variables such as years under central planning and the EU membership dummy variable. It can be assumed that the achievements in transition countries are determined to some extent by how deeply rooted the formal and informal institutions linked to central economic planning are and the nature of prior economic development (the 'path dependence' effect hypothesis).

The variable CENTRAL PLANNING represents the number of years under central planning and shows how long transition countries experienced direct state involvement in economic processes. We included the dummy variable NON-EU, which is given the value 1 if a country is not a member of the EU and 0 otherwise. For transition countries, the EU accession process represents one of the main systemic incentives for a fundamental transformation of the institutional setting. The EU played the role of external anchor, ensuring the implementation of market economy norms and the establishment of democratic institutions in these countries (Roland, 2004). It is widely believed that institutional transformation in European transition countries was closely linked to the process of EU accession. Since the level of institutional quality in the majority of transition countries is far below that advocated by the EU, we expected this coefficient to have a negative and significant impact on FDI inflows.

WGIs are developed by Kaufmann et al. (2010: 4), who defined governance as 'the traditions and institutions by which authority in a country is exercised'. These measurements are based on expert evaluations and surveys of households and businesses related to different areas of the institutional setup. They cover three significant aspects of institutional setting. Namely, one can identify the following groups of governance indicators:

- the first group of measures (VA and PSAV) assesses 'the process by which governments are selected, monitored and replaced';

- the second group of measures (GE and RL) captures 'the capacity of the government to effectively formulate and implement sound policies';

- the third group of measures (CC and RQ) shows 'the respect of citizens and the state for the institutions that govern economic and social interactions among them'.

It should be noted that VA and PSAV primarily measure the strength of political institutions in contrast to the other WGIs. We believe that these two indicators are related to those aspects of the institutional setting covered by the Freedom House data (Civil rights, Political rights). 
According to the descriptive statistics in Table 1, the economic development indicators in the transition countries differ to a great extent. For example, the mean FDI as a percentage of GDP for the total sample is $5.76 \%$, with a standard deviation of 7.49. We also found wide variations in openness to trade, gross fixed capital formation, the level of inflation and GDP growth. For instance, the trade openness variable was between 29.75 and $192.34 \%$ with an average of $102.92 \%$ and a standard deviation of 32.36. The mean values of the governance indicators ranged from -0.26 to 0.16 , while their medians ranged from 0.66 (for $\mathrm{CC}$ ) to 0.89 (for VA). The RQ variable had the highest mean value (0.16) among the governance factors.

Table 1: Descriptive statistics

\begin{tabular}{|l|r|r|r|r|r|}
\hline \multicolumn{1}{|c|}{ Variable } & Obs & \multicolumn{1}{c|}{ Mean } & Std. Dev. & \multicolumn{1}{c|}{ Min } & \multicolumn{1}{c|}{ Max } \\
\hline FDI & 459 & 5.760 & 7.490 & -46.769 & 55.075 \\
\hline GDPG & 459 & 4.200 & 4.654 & -14.814 & 34.466 \\
\hline OPEN & 457 & 102.919 & 32.366 & 29.748 & 192.345 \\
\hline GFCF & 457 & 23.889 & 5.681 & 6.3 & 57.71 \\
\hline INF & 459 & 5.665 & 6.546 & -1.601 & 59.218 \\
\hline POLRIGHTS & 451 & 3.292 & 2.096 & 1 & 7 \\
\hline CIVLIBERTIES & 451 & 3.066 & 1.736 & 1 & 7 \\
\hline STATUS & 451 & 0.536 & 0.4992 & 0 & 1 \\
\hline CENTRAL PLANNING & 459 & 55.370 & 12.707 & 41 & 74 \\
\hline NON-EU & 459 & 0.673 & 0.469 & 0 & 1 \\
\hline OWGI & 455 & $3.08 \mathrm{e}-09$ & 2.293 & -4.883 & 4.233 \\
\hline CC & 459 & -0.260 & 0.663 & -1.415 & 1.506 \\
\hline VA & 459 & -0.021 & 0.895 & -2.124 & 1.213 \\
\hline PSAV & 455 & 0.028 & 0.719 & -2.020 & 1.302 \\
\hline RL & 459 & -0.136 & 0.737 & -1.476 & 1.372 \\
\hline RQ & 456 & 0.166 & 0.772 & -1.710 & 1.698 \\
\hline GE & 456 & 0.004 & 0.671 & -1.230 & 1.192 \\
\hline
\end{tabular}

Source: Authors' calculations

In Table 2, we have provided the correlation matrix for FDI and its determinants in order to assess whether there are significant associations between the analysed variables. When the correlation coefficient is greater than 0.6 , the relationship between the variables is considered to be significant, which may call into question efficient and reliable parameter estimation and thus the validity of the model. The correlation coefficients between various governance dimensions, as well as indicators of democracy, have a value higher than 0.7 , which might indicate the presence of multicollinearity. In order to avoid this problem, we decided to include them separately in our regressions. 
Jelena Zvezdanović Lobanova et al. • Governance and civil and political rights as FDI... Zb. rad. Ekon. fak. Rij. $2021 \cdot$ vol. $39 \cdot$ no. $1 \cdot 59-86$

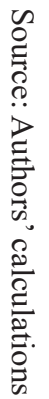

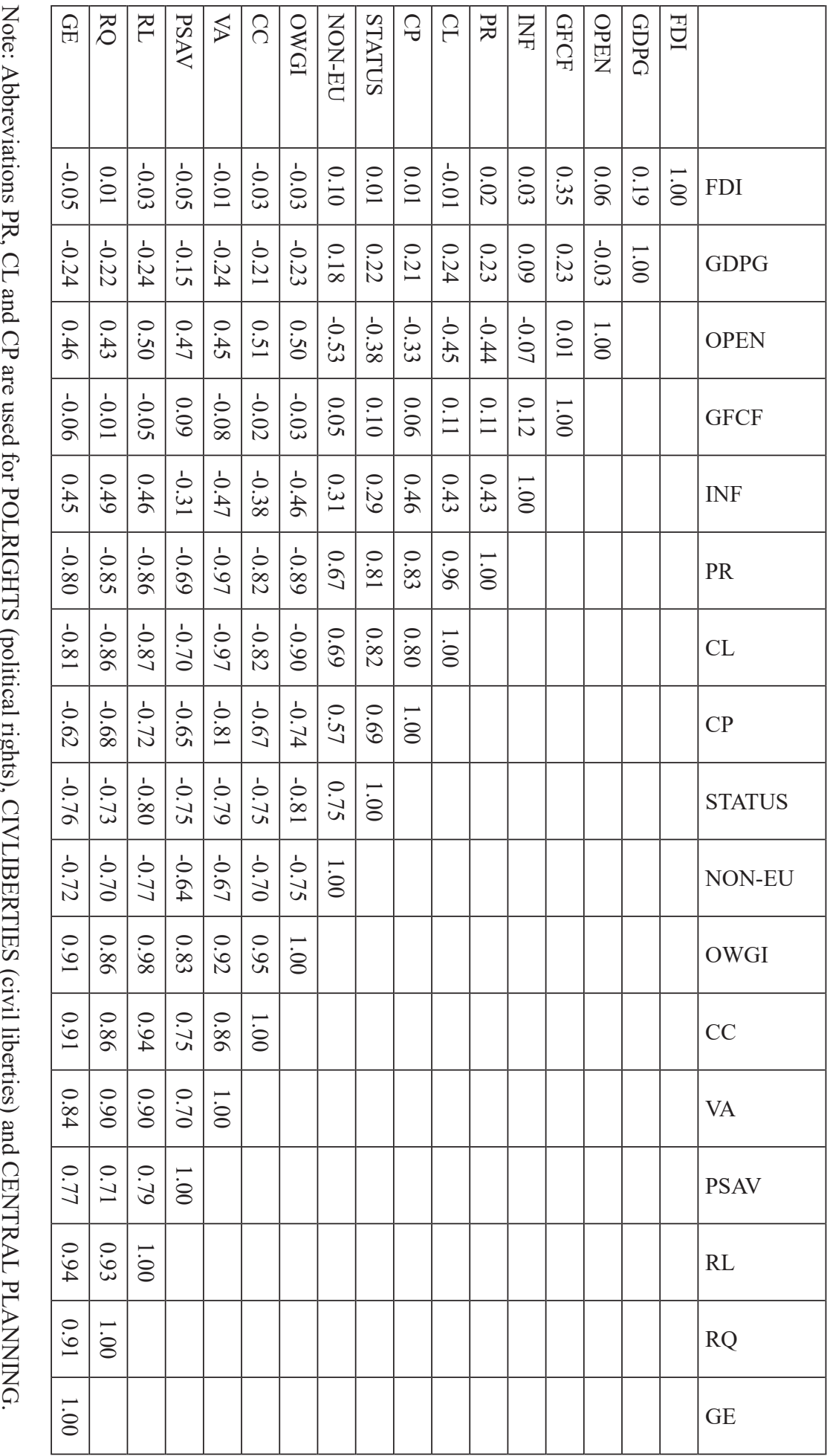


According to the p-values of the Hansen test statistics reported in Table 3, we can conclude that the instruments are uncorrelated with errors. Therefore, our results show that the instruments are valid at conventional levels of statistical significance. The test statistic for second-order serial correlation also suggests that there is no second-order serial correlation in the first differences in the residuals in all specifications. In column 1 of Table 3, we have presented the results of our baseline model, while in columns 2-6, we have assessed the influence of democracy variables on FDI attraction.

The coefficient of lagged FDI inflows is positive and significant at the $1 \%$ level in all the tables. Therefore, we found that the agglomeration effect has a positive influence on FDI inflows in transition countries. The value of this coefficient is below 1, which points to the existence of convergence. GDP growth has the sign we expected, but the coefficient is not significant in any of our regressions. It seems that this variable is not of decisive importance for FDI attraction in the selected countries.

We found that trade openness does not contribute positively to an increase in FDI inflows. These coefficients are negative and significant at the 5\% level. Trade openness does not contribute positively to an increase in FDI inflows. In some circumstances, trade openness can lead to the excessive dependence of economic growth on external market factors and, therefore, may trigger macroeconomic imbalances. Moreover, trade openness provides indirect evidence of the absence of foreign trade barriers, so it reduces the interest of potential investors in FDI: companies can expand into new markets through cross-border commodity deliveries without investing in the creation of production sites. On the other hand, investments in the development of different kinds of infrastructure (industrial, transport, and social) are among the important incentives for TNCs to invest abroad.

The significant positive coefficients of GFCF show that investments in developing different kinds of infrastructure (industrial, transport, and social) are among the important incentives for TNCs to invest abroad, which is in line with the findings of Asiedu and Lien (2011). The coefficient of inflation in Table 3 exhibits a mixed pattern, but is not statistically significant in any of the models. 


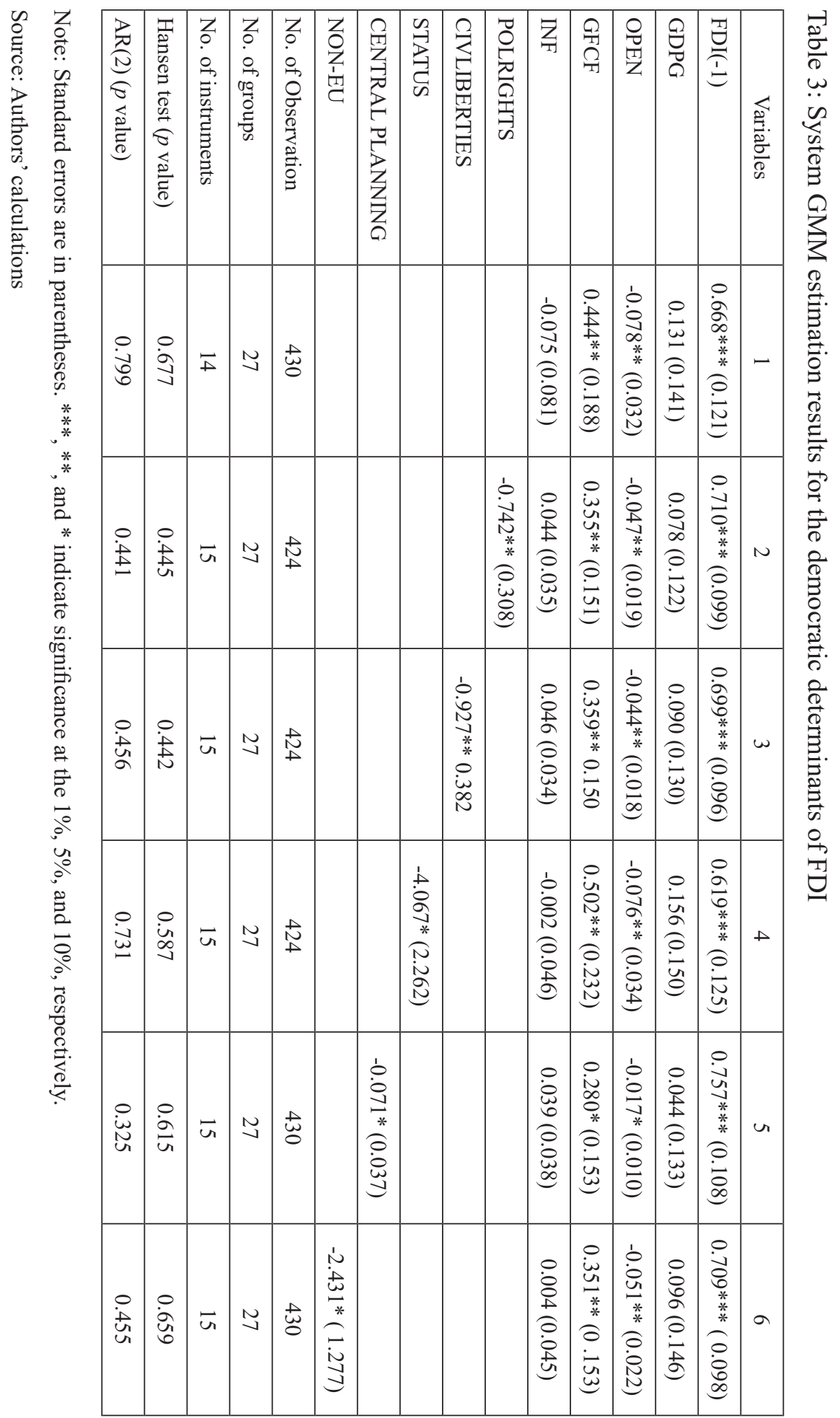


Our findings reveal a negative and significant coefficient of political rights on FDI, meaning that countries with increasing concerns over political rights discourage foreign investors. We also found that less protection of fundamental basic rights also reduces investment inflows, while an uncertain political situation and violations of civil liberties weigh heavily on foreign investors' confidence. The coefficient of central planning and the dummy variable Status are significant and have the expected signs. Countries classified as partly free or not free due to difficulties in establishing political rights and civil liberties are also less attractive to foreign investors. The coefficient of the Non-EU dummy variable is negative and significant, indicating that non-EU transition countries had fewer FDI inflows during the period under consideration.

Based on the GMM diagnostics in Table 4, we note that the p-value of the Hansen test statistic is relatively high, suggesting instrument validity. We did not find evidence for the presence of second-order serial correlation in the first-difference residuals. In all our regressions, the lagged dependent variable has the correct sign and significance, which provides evidence for the dynamic nature of FDI inflows in transition countries. The estimated coefficients for current GDP growth are positive but not statistically significant in all the columns. Trade openness carries a negative sign and it is statistically significant at the conventional level of 0.05 .

The coefficients of control of corruption (CC) and voice and accountability (VA) are positive and statistically significant, while other governance indicators also turned out to be positive but insignificant. We can assume that these governance indicators are among the factors influencing the investment activities of multinationals in transition countries. Voice and accountability as a proxy for the level of pluralism in a country reveal the process of establishing, monitoring, and replacing government bodies. Therefore, we have provided evidence that an improvement in political and human rights ratings is important for foreign investors in transition countries.

Table 5 presents results using the interaction terms between GDP growth and the quality of the institutional setting measured by both the overall and separate governance indicators. The large p-values of the Hansen test statistics are taken as evidence of the validity of the instrument subsets. The coefficients of the current GDP growth rate range from 0.127 to 0.173 according to these particular regressions, but they are not statistically significant at conventional levels. The coefficients of trade openness are negative and statistically significant in all our regressions, which means that higher trade openness discourages FDI inflows in transition countries. Gross fixed capital formation is positively and significantly associated with FDI inflows in all columns in this table. Inflation has the expected sign, but it continues to be insignificant in all regressions. 


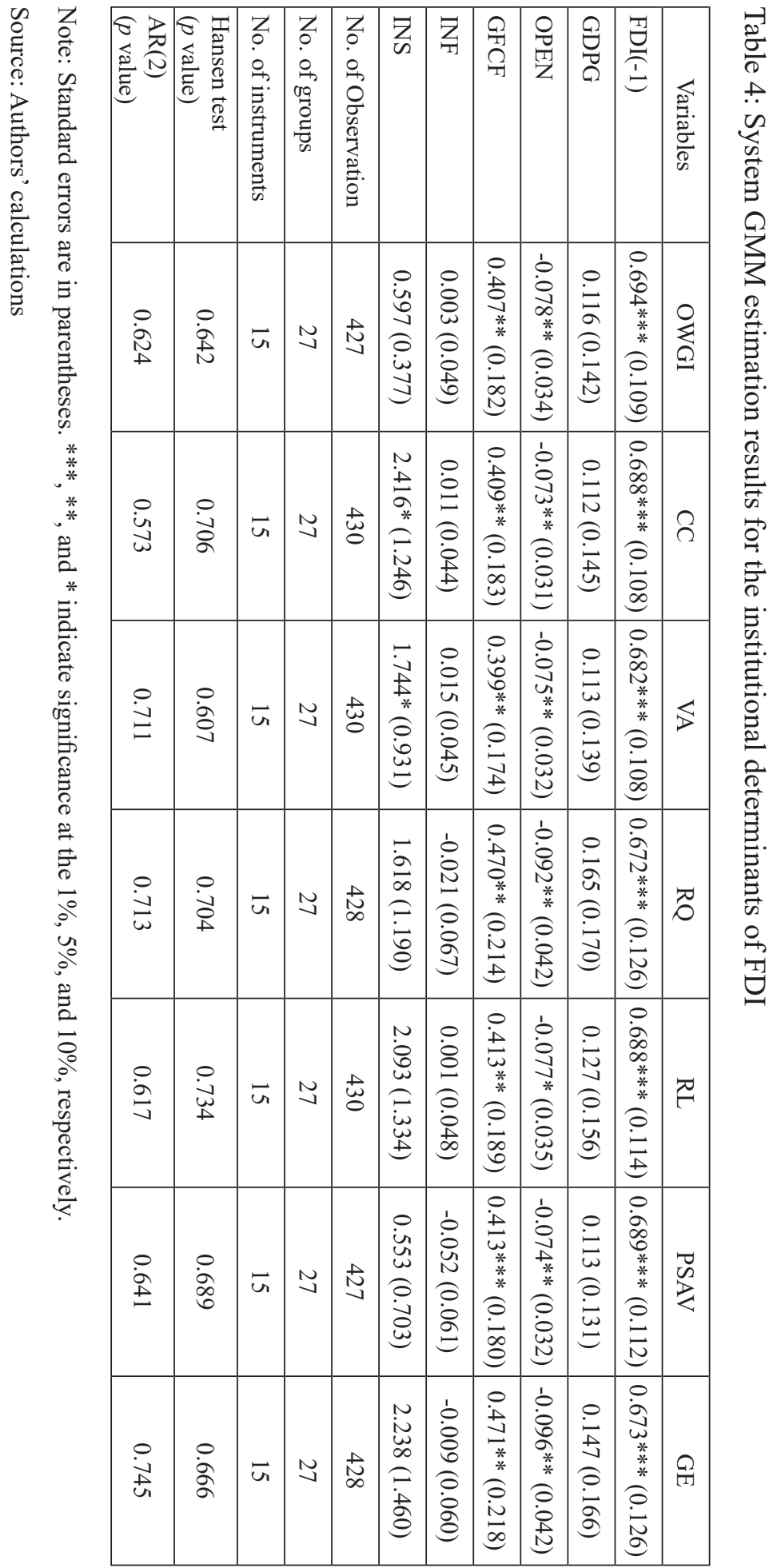




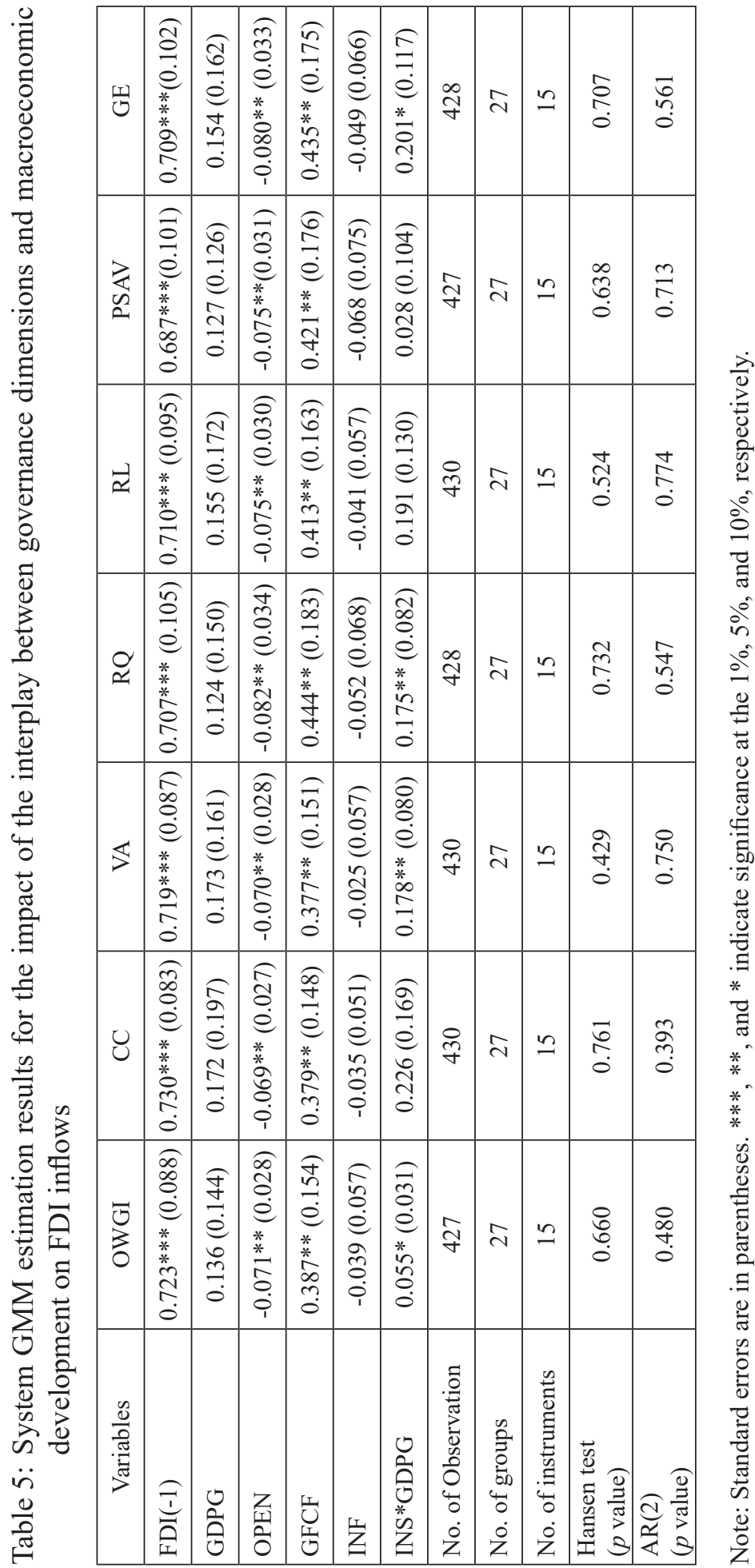

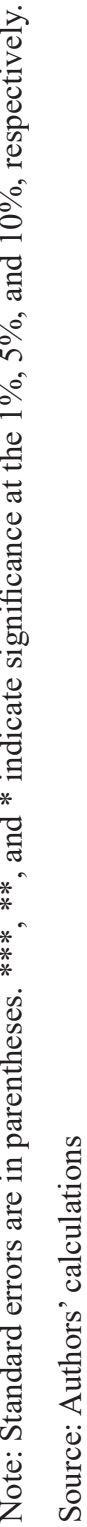


The synergetic effects captured by the interactive terms are all positive but the only significant coefficient is between GDP growth and VA, RQ, GE, and overall WGI. In other words, the creation of conditions for stimulating foreign investors via the improvement of institutional quality combined with favourable macroeconomic development has reflected positively on FDI inflows. Based on the magnitude of the coefficients mentioned above, the interaction term with VA has the strongest influence on FDI inflows followed by RQ. Therefore, it can be assumed that foreign investors are not attracted by the quality of institutional setting alone, but they also take into account the effectiveness of economic development.

\section{Results and discussion}

Using system GMM, we have found out that the agglomeration effect has a positive influence on FDI inflows in transition countries. This means that FDI recipients manage to create a virtuous circle of attracting investment, which then greatly encourages the attraction of more foreign investment into these countries. Therefore, the agglomeration effect leads to the further differentiation of transition countries in terms of the tempo of FDI accumulation. Our results also show that investments in developing different kinds of infrastructure are among the important incentives for TNCs to invest abroad, which is in line with the findings of Asiedu and Lien (2011).

Contrary to the earlier findings by Younsi and Bechtini (2019), Ezeoha and Cattaneo (2012) and Jadhav (2012), who demonstrated that trade openness attracts more FDI inflows, our findings show that trade openness discourages foreign investors. It is noteworthy that our conclusion is in line with the results of some other studies such as Brun and Gnangnon (2017), Walsh and Yu (2010), and Bobenič Hintošova et al. (2018). The obtained results could be explained in two ways. Firstly, higher trade openness in some countries could prove a disincentive for foreign investors. Namely, in some circumstances trade openness can lead to the excessive dependence of economic growth on external market factors, and therefore, they may trigger macroeconomic imbalances. Secondly, trade openness is indirect evidence of the absence of foreign trade barriers, so it reduces the interest of potential investors in FDI: companies can expand into new markets through cross-border commodity deliveries without investing in the creation of production sites.

The following example can illustrate this assumption. The transition of the Visegrad group states to the EU common external tariffs applicable to third countries contributed to a decrease in the weighted average rate of import duty, but for some types of industrial products (including household electrical appliances and electronics) it increased. As a result, in the mid-2000s, Asian companies began to actively create production sites in the Visegrad group countries in order to 
avoid paying customs duties (so-called 'anti-dumping tariff jumping') (see, for example, Ando and Kimura (2013)). In addition, it has been estimated that while the improvement of the terms of foreign trade (for example, by signing free trade agreements) has a positive effect on the volume of commodity flows, it often has a negative effect on capital inflows.

Our empirical findings indicate that insufficient attention to respect for political rights and civil liberties has a negative and significant effect on FDI inflows in transition countries. Multinational companies may be reluctant to invest in transition countries that have experienced a substantial deterioration in political rights. A democratic deficit and unfavourable environment for the promotion and respect of civil society values have harmed the willingness of foreign investors to take a risk in some of these countries. In conditions where the gap between the political elites and society is widening, which has culminated in the erosion of civil liberties in some transition countries, there is a justifiable fear that foreign investors' rights, including those concerning intellectual property, will not be adequately protected. Our findings are consistent with the results of Adam and Filippaios (2007), Harms and Ursprung (2002), and Kucera and Principi (2017), who also shows that the development of democratic society institutions results in additional FDI inflows.

Moreover, we have found out that those transition countries that experienced longer periods of central planning also recorded a lower level of FDI inflows. It can be assumed that it is difficult for these countries to overcome the structural imbalances of the economy, rooted during the development of the planned economy, and thereby to improve the investment climate (a negative 'lock-in' effect). Countries classified as partly free or not free due to difficulties in securing political rights and civil liberties were also less attractive to foreign investors. Our findings provide evidence that those transition countries which did not become EU members received fewer FDI inflows than the others included in our analysis. Most probably these countries were less attractive to foreign investors since they did not have the stable institutional framework necessary for the functioning of a market economy. The implementation of economic reforms slowed down or was even suspended as a result of adverse economic, political and social developments in these countries. The existing institutional arrangements were serious impediments to the economic development of the post-socialist countries since they were not able to adapt successfully to the changing conditions.

We found that control of corruption and voice and accountability were the main drivers of FDI inflows in transition countries (among the governance indicators). We have shown that FDI inflows are positively and significantly affected by improvements in these areas of institutional quality. In those countries where public power is commonly used for private gains (the 'state capture' phenomenon), higher amounts of FDI are less probable. A similar result was obtained by Sabir et al. (2019), who also points out that FDI inflows in developing countries are positively 
and significantly affected by control of corruption, government effectiveness and political stability. The concentration of power by a limited circle of representatives of the political elite in some countries is usually accompanied by corruption that limits business opportunities. In conditions of legal uncertainty, foreign investors are put at a disadvantage since local companies could be more familiar with non-transparent business procedures, weak judicial systems, complicated legal and regulatory frameworks, etc. Therefore, investors feel safe if their rights are protected and the operational rules are developed and enforced by independent institutions.

Our conclusion that a higher level of democracy improves competitiveness for FDI attraction confirms the findings by Lucke and Eicher (2016), and Harms and Ursprung (2002). However, it contradicts the results of Mengistu and Adkihary (2012), who failed to provide evidence that voice and accountability and regulatory quality have a significant impact on FDI inflows in Asian economies. It is also inconsistent with the findings of Younsi and Bechtini (2019), which indicate that voice and accountability, rule of law and control of corruption are negatively and significantly linked to FDI inflows in emerging markets.

Our results indicate that the impact of the quality of institutions on FDI inflows is conditional on the macroeconomic performance of transition countries. We argue that GDP growth has a positive impact on the marginal effects of overall institutional quality as well as on voice and accountability, regulatory quality and government efficiency. The coefficient of the interaction term between the overall WGI and GDP growth is positive and significant. It means that macroeconomic development has a positive impact on the marginal effect of institutional quality. Therefore, the efforts made in areas such as the quality of public services, the transparency of economic regulation, and the promotion of the private sector play an important role in FDI attraction in transition countries. Foreign investors expect improvements in the legal framework, a rise in institutional capacity, and a reduction in administrative barriers.

\section{Conclusion}

The primary aim of this study was to investigate the FDI determinants in 27 transition countries within the 2002-2018 period by employing the system GMM analysis. The results confirmed the main hypothesis that respect for political rights and civil liberties could lead to an increase in FDI inflows into host transition countries. Among the governance indicators, corruption and voice and accountability were found to be the key drivers for FDI attraction. Our findings indicated that benefiting from an improved institutional environment requires favourable macroeconomic conditions. Specifically, we found that GDP growth affects FDI inflows positively and significantly in condition of improved 
institutional quality, especially voice and accountability, regulatory quality and government efficiency.

This paper contributes to the literature on determinants of FDI attraction in transition countries. In particular, we studied the joint impact of institutional quality and macroeconomic development. Our emphasis was on the institutional factors which may be crucial for all types of FDI. The decision made on independent variables was based on the previous research, and on existing theoretical knowledge on possible determinants of FDI inflows. We relied on the open data sources on the quality of the institutional setting that has been widely used in scholarly research. However, many of these indices are very subjective in many cases, because they reflect expert opinion on a few different areas of institutional quality. In addition, we acknowledge that we could not address the majority of factors that influence the foreign investment decisions. Therefore, we suppose that our empirical research could be extended and enriched by including factors related to different types of FDI. The attractive factors are, to a great extent, dependent on the motivation of the investor, i.e. different factors influence resource-seeking, efficiency-seeking, market-seeking and strategic asset-seeking FDI.

Our findings have important implications for policymakers from countries in transition. Their major problem is not only providing a constitutional and legal framework for democracy and civil liberties but also securing the newly established economic and political freedoms that support competition. Fundamental rights are largely enshrined in the legislation of these countries, but it is necessary to ensure that they are fully implemented in practice. Democracy should not only be accepted formally, but there also has to be the protection of human rights and the creation of conditions for the development of political culture and a high degree of political participation. In order to increase the FDI attractiveness, institutional strengthening of transition countries is of key importance, which implies the introduction of democratic, legal, and economic institutions and improving administration and the judiciary so these institutions can function unhindered. In addition, policymakers are expected to make more effort to stimulate sustainable socio-economic development to produce a positive and significant marginal effect of institutional quality on FDI inflows. Transition countries may ensure higher FDI inflows and faster economic development by increasing the quality of institutional arrangements to catch up with developed countries.

\section{References}

Adam, A., Filippaios, F. (2007) "Foreign Direct Investment and Civil Liberties: A New Perspective", European Journal of Political Economy, Vol. 23, No. 4, pp. 1038-1052, https://doi.org/10.1016/j.ejpoleco.2006.08.006. 
Ando M., Kimura F. (2013) "Production linkage of Asia and Europe via Central and Eastern Europe", Journal of Economic Integration, Vol. 28, No. 2, pp. 204-240, https://doi.org/10.11130/jei.2013.28.

Arellano, M., Bond, S. (1991) "Some Tests of Specification for Panel Data: Monte Carlo Evidence and an Application to Employment Equations", Review of Economic Studies, Vol. 58, No. 2, pp. 277-297, https://doi.org/10.2307/2297968.

Asiedu, E., Lien, D. (2011) "Democracy, foreign direct investment and natural resources", Journal of International Economics, Vol. 84, No. 1, pp. 99-111, https://doi.org/10.1016/j.jinteco.2010.12.001.

Asongu, S. A., Akpan, U. S., Isihak, S. R. (2018) "Determinants of Foreign Direct Investment in Fast-Growing Economies: Evidence from the BRICS and MINT Countries", Financial Innovation, Vol. 4, No. 26, pp. 1-17, https://doi. org/10.1186/s40854-018-0114-0.

Azis, O. G. (2018) "Institutional quality and FDI inflows in Arab economies", Finance Research Letters, Vol. 25, pp. 111-123, https://doi.org/10.1016/j. frl.2017.10.026.

Bevan, A., Estrin, S., Meyer, K. (2004) "Foreign Investment Location and Institutional Development in Transition Economies", International Business Review, Vol. 13, No. 1, pp. 43-64, https://doi.org/10.1016/j.ibusrev.2003.05.005.

Blundell, R., Bond, S. (1998) "Initial Conditions and Moment Restrictions in Dynamic Panel Data Models", Journal of Econometrics, Vol. 87, No. 1, pp. 115-143, https://doi.org/10.1016/S0304-4076(98)00009-8.

Blundell, R., Bond, S., Windmeijer, F. (2000) "Estimation in Dynamic Panel Data Models: Improving on the Performance of the Standard GMM Estimator", IFS Working Paper (W00/12), The Institute for Fiscal Studies, http://dx.doi. org/10.1920/wp.ifs.2000.0012.

Bobenič Hintošova, A. et al. (2018) "Determinants of foreign direct investment flows: A case of the Višegrad countries", Journal of International Studies, Vol. 11, No. 2, pp. 222-235, https://doi.org/10.14254/2071-8330.2018/11-2/15.

Brun, J-F., Gnangnon, S. K. (2017) "Does Trade Openness contribute to driving Financing Flows for Development?" WTO Working Paper ERSD-2017-0, https://www.wto.org/english/res_e/reser_e/ersd201706_e.pdf.

Bun, M. J. G, Windmeijer, F. (2010) "The weak instrument problem of the system GMM estimator in dynamic panel data models", Econometrics Journal, Vol. 13, No. 1, pp. 95-126, https://doi.org/10.1111/j.1368-423X.2009.00299.x.

Chanegriha, M., Stewart,, C., Tsoukis, C. (2017) "Identifying the robust economic, geographical and political determinantts of FDI: an Extreme Bounds Analysis", Empirical Economics, Vol. 52, No. 2, pp. 759-776, https://doi.org/10.1007/ s00181-016-1097-1.

Damijan, J. P. et al. (2003) "The role of FDI, R\&D accumulation and trade in transferring technology to transition countries: evidence from firm panel data 
for eight transition countries", Economic systems, Vol. 27, No. 2, pp. 189-204, https://doi.org/10.1016/S0939-3625(03)00039-6.

Dellis, K., Sondermann, D., Vansteenkiste, I. (2017) "Determinants of FDI Inflows in Advanced Economies: Does the Quality of Economic Structure Matter?" Working Paper Series. No. 2066, https://www.ecb.europa.eu/pub/pdf/scpwps/ ecb.wp2066.en.pdf.

Demirhan, E., Masca, M. (2008) "Determinants of Foreign Direct Investment Flows to Developing Countries: A Cross Sectional Analysis", Prague Economic Papers, Vol. 17, No. 4, pp. 356-369, https://doi.org/10.18267/j.pep.337.

Dikova, D., Witteloostuijn, A. (2007) "Foreign Direct Investment Mode Choice: Entry and Establishment Modes in Transition Economies", Journal of International Business Studies, Vol. 38, pp. 1013-1033, https://doi.org/10.1057/ palgrave.jibs. 8400297.

Dunning, J. (2000) "The Eclectic Paradigm as an Envelope for Economic and Business Theories of MNE Activity", International Business Review, Vol. 9, No. 2, pp. 163-190, https://doi.org/10.1016/S0969-5931(99)00035-9.

Dunning, J., Lundan, S. (2008) Multinational Enterprises and the Global Economy (second edition). Cheltenham, UK: Edward Elgar.

Economou, F. (2019) "Economic freedom and asymmetric crisis effects on FDI inflows: The case of four South European economies", Research in International Business and Finance, Vol. 49, pp. 114-126, https://doi. org/10.1016/j.ribaf.2019.02.011.

Ezeoha, A. E., Cattaneo, N. (2012) "FDI Flows to Sub-Saharan Africa: The Impact of Finance, Institutions and Natural Resource Endowment", Comparative Economic Studies, Vol. 54, pp. 597-632, https://doi.org/10.1057/ces.2012.18.

Fabry, N., Zeghni, S. (2006) "How Former Communist Countries of Europe May Attract Inward Foreign Direct Investment? A Matter of Institutions", Communist and Post-Communist Studies, Vol. 39, No. 2, pp. 201-219, https://doi. org/10.1016/j.postcomstud.2006.03.006.

Fabry, N., Zeghni, S. (2010) "Inward FDI in Seven Transitional Countries of SouthEastern Europe: A Quest of Institution-based Attractiveness", Eastern Journal of European Studies, Vol. 1, No. 2, pp. 77-90, https://hal.archives-ouvertes.fr/ hal-01100288.

Harms, P., Ursprung, H. W. (2002) "Do civil and political repression really boost foreign direct investments? ”, Economic Inquiry, Vol. 40, No. 4, pp. 651-663, https://doi.org/10.1093/ei/40.4.651.

Islam, R., Montenegro, C. E. (2002) "What determines the quality of institutions?" Policy, Research working paper series No. WPS 2764 Washington, D.C.: World Bank Group, https://openknowledge.worldbank.org/handle/10986/15725. 
Jadhav, P. (2012) "Determinants of foreign direct investment in BRICS economies: Analysis of economic, institutuional and political factor", Procedia - Social and Behavioral Sciences, Vol. 37, pp. 5-14, https://doi.org/10.1016/j. sbspro.2012.03.270.

Kaufmann, D., Kraay, A., Mastruzzi, M. (2010) "The Worldwide Governance Indicators: Methodology and Analytical Issues", World Bank Policy Research Working Paper No. 5430, https://ssrn.com/abstract=1682130.Kazemi, M., Azman-Saini, W. N. W. (2017) "Foreign Direct Investment, Economic Freedom and Democracy", International Journal of Economics and Management, Vol. 11, No. 1, pp. 1-15, http://www.ijem.upm.edu.my/vol11no1/(1)-Paper\%20 01\%20Final-IJEM\%2011(1),2017_FDI\%20Demo.pdf.

Kucera, D. C., Principi, M. (2017) "Rights, governance and foreign direct investment: an industry-level assessment", International Review of Applied Economics, Vol. 31, No. 4, pp. 468-494, https://doi.org/10.1080/02692171.201 6.1263606 .

Kurtovic, S., Maxhuni, N., Halili, B., Talović, S. (2020) “The determinants of FDI location choice in the Western Balkan countries", Post-Communist Economies, Vol. 32, No. 8, pp. 1089-1110, https://doi.org/10.1080/14631377.2020.172258.

Lacroix, J., Meon, P. G., Sekkat, K. (2018) "Do democratic Transitions Attract Foreign Investors? If So, How Fast?” CEB Working Paper 17/006, https://dipot. ulb.ac.be/dspace/bitstream/2013/246943/3/wp17006.pdf.

Lipschitz, L., Lane, T., Mourmouras, A. (2001) "Capital Flows to Transition Economies: Master of Servant?" IMF Working Paper, https://doi. org/10.5089/9781451842791.001.

Lucke, N., Eichler, S. (2016) "Foreign direct investment: the role of institutional and cultural determinants", Applied Economics, Vol. 48, No. 11, pp. 935-956, https://doi.org/10.1080/00036846.2015.1090551.

Mahmood, N. et al. (2019) "Foreign direct investment and institutional stability: who drives whom?", Journal of Economics, Finance and Administrative Scince, Vol. 24, No. 47, pp. 145-156, https://doi.org/10.1108/JEFAS-05-2018-0048.

Mengistu, A. A., Adhikary, B. K. (2011) "Does good governance matter for FDI inflows? Evidence from Asian economies", Asia Pacific Business Review, Vol. 17, No. 3, pp. 281-299, https://doi.org/10.1080/13602381003755765.

Paul, J., Jadhav, P. (2020) "Institutional determinants of foreign direct investment inflows: evidence from emerging markets", International Journal of Emerging Markets, Vol. 15, No. 2, pp. 245-261, https://doi.org/10.1108/ IJOEM-11-2018-0590.

Peres, M., Ameer, W., Xu, H. (2018) "The impact of institutional quality on foreign direct investment inflows: evidence for developed and developing countries", Economic research - Ekonomska istraživanja, Vol. 31, No. 1, pp. 626-644, https://doi.org/10.1080/1331677X.2018.1438906. 
Roland, G. (2004) "After Enlargement: Institutional Achievements and Prospects in the New Member States". In Detken, C., Gaspar, V., Noblet, G. eds., The New EU Member States - Convergence and Stability, European Central Bank, pp. 35-58, https://www.ecb.europa.eu/pub/pdf/other/neweumemberstatesen2005en. pdf.

Roodman, D. (2009) "How to Do xtabond2: An Introduction to "Difference" and "System" GMM in Stata", Stata Journal, Vol. 9, No. 1, pp. 86-136, https://doi. org/10.1177/1536867X0900900106.

Sabir, S., Rafique, A., Abbas, K. (2019) "Institutions and FDI: Evidence from developed and developing countries", Financial Innovation, Vol. 5, No. 8, pp. 1-20, https://doi.org/10.1186/s40854-019-0123-7.

Shukurov, S. (2016) "Determinants of FDI in transition Economies: The Case of CIS Countries", Journal of International and Global Economic Studies, Vol. 9, No. 1, pp. 75-94, https://www2.southeastern.edu/orgs/econjournal/index_files/ JIGES\%20JUNE\%202016\%208-15-2016\%20Shukurov\%20Sobir_Uzbekistan. pdf.

Wach, K., Wojciechowski, L. (2016) "Determinants of inward FDI into Visegrad countries: empirical evidence based on panel data for the years 2000-2012", Economic and Business Review, Vol. 2, No. 16, pp. 34-52, https://doi. org/10.18559/ebr.2016.1.3.

Walsh, J. P., Yu, J. (2010) "Determinants of FDI: A Sectoral and Institutional Approach", IMF Working Paper, No. 10/187, https://www.imf.org/en/ Publications/WP/Issues/2016/12/31/Determinants-of-Foreign-DirectInvestment-A-Sectoral-and-Institutional-Approach-24135.

Windmeijer, F. (2005) "A Finite Sample Correction for the Variance of Linear Efficient Two-step GMM Estimators", Journal of Econometrics, Vol. 126, No. 1, pp. 25-51, https://doi.org/10.1016/j.jeconom.2004.02.005.

Younsi, M., Bechtini, M. (2019) "Does governance matter for FDI? New evidence from emerging countries using a static and dynamic panel gravity model approach", Economics of Transition and Institutional Change, Vol. 27, No. 3, pp. 841-860, https://doi.org/10.1111/ecot.12224. 


\title{
Upravljanje i građanska i politička prava kao odrednice inozemnih izravnih ulaganja u tranzicijskim zemljama ${ }^{1}$
}

\author{
Jelena Zvezdanović Lobanova ${ }^{2}$, Mikhail Lobanov ${ }^{3}$, Milan Zvezdanović ${ }^{4}$
}

\begin{abstract}
Sažetak
Cilj ovog rada bio je istraživanje odrednica izravnih stranih ulaganja u 27 tranzicijskih zemalja u razdoblju od 2002. do 2018. godine, uz pomoć sistemskog GMM procjenitelja. Otkrili smo da neizvjesna politička situacija i kršenje građanskih sloboda imaju značajan negativan utjecaj na povjerenje stranih ulagača. Općenito, erozija demokratskih institucija odvraća priljev izravnih stranih ulaganja. Zemlje u tranziciji koje su imale duža razdoblja centralnog planiranja također su zabilježile niže nivoe priljeva SDI. Rezultati pokazuju da je stvaranje uvjeta za privlačenje stranih ulagača, uz pomoć poboljšanja institucionalne kvalitete $u$ vidu kontrole korupcije i glasa i odgovornosti, pozitivno utjecalo na priljev SDI. Međudjelovanje ukupne institucionalne kvalitete, glasa $i$ odgovornosti, regulatorne kvalitete, učinkovitosti Vlade i rasta BDP-a su pozitivna i značajna; prema tome, makroekonomski razvoj ima značajan utjecaj na granični učinak institucionalne kvalitete. Stoga smo zaključili da utjecaj upravljanja na priljev SDI ovisi o makroekonomskim performansama tranzicijskih zemalja. Naši rezultati također otkrivaju da, među upravljačkim dimenzijama, kontrola korupcije i glas i odgovornost imaju značajan utjecaj na odluke multinacionalnih kompanija o poduzimanju investicija.
\end{abstract}

Ključne riječi: izravna strana ulaganja, institucije, građansko društvo, demokracija, tranzicijske zemlje

JEL klasifikacija: D73, E22, F21, F23, O52

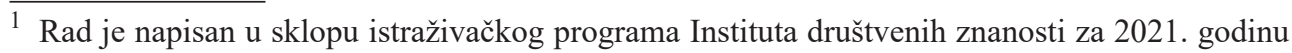
koji podržava Ministarstvo prosvjete, znanosti i tehnološkog razvoja Republike Srbije.

2 Znanstveni suradnik, Centar za ekonomska istraživanja, Institut društvenih znanosti, Kraljice Natalije 45, 11000 Beograd, Srbija. Znanstveni interes: međunarodni tokovi kapitala, prekogranična spajanja i preuzimanja, kvalitet institucionalnog okruženja. Tel.: +381113616002.E-mail: jzvezdanovic@idn.org.rs.

3 Zamjenik ravnatelja za istraživanje, Viši znanstveni suradnik, Ekonomski institut, Ruska akademija znanosti, Nakhimovskiy pr. 32, 117997 Moskva, Ruska Federacija. Znanstveni interes: problem socijalno-ekonomskog $i$ političkog razvoja srednje, istočne i jugoistočne Europe, proširenje Europske unije, funkcionalna i teritorijalna organizacija industrije $i$ poljoprivrede $i$ varijeteti kapitalističnih odnosa. Tel.: +74997241541.E-mail: m.m.lobanov@ yandex.ru.

4 Docent, Akademija za nacionalnu sigurnost, Kraljice Ane bb, 11000 Beograd, Srbija. Znanstveni interes: spajanja i preuzimanja, korporativni menadžment, korupcija i institucionalni razvoj. Tel.: +381648495255.E-mail: zvezdanovicmilan@gmail.com. 


\section{Appendix: A list of the variables included in the analysis}

\begin{tabular}{|c|c|c|}
\hline Variables & Definition & Source \\
\hline \begin{tabular}{|l|} 
Foreign Direct \\
Investment (FDI)
\end{tabular} & FDI inflows as a percentage of GDP & $\begin{array}{l}\text { World Bank World } \\
\text { Development Indicators }\end{array}$ \\
\hline $\begin{array}{l}\begin{array}{l}\text { GDP growth } \\
\text { (GDPG) }\end{array} \\
\end{array}$ & Annual percentage growth rate of GDP & $\begin{array}{l}\text { World Bank World } \\
\text { Development Indicators }\end{array}$ \\
\hline $\begin{array}{l}\text { Trade Openness } \\
(\text { OPEN) }\end{array}$ & Trade as percentage of GDP & $\begin{array}{l}\text { World Bank World } \\
\text { Development Indicators }\end{array}$ \\
\hline $\begin{array}{l}\text { Gross fixed capital } \\
\text { formation (GFCF) }\end{array}$ & $\begin{array}{l}\text { Gross fixed capital formation as percentage } \\
\text { of GDP }\end{array}$ & $\begin{array}{l}\text { World Bank World } \\
\text { Development Indicators }\end{array}$ \\
\hline $\begin{array}{l}\text { Inflation } \\
\text { (INF) }\end{array}$ & Average consumer prices, percentage change & $\begin{array}{l}\text { World Economic Outlook } \\
\text { database developed by the } \\
\text { International Monetary } \\
\text { Fund }\end{array}$ \\
\hline $\begin{array}{l}\text { Civil Rights } \\
\text { (CIVLIBERTIES) }\end{array}$ & $\begin{array}{l}\text { The civil liberties' rating includes four } \\
\text { subcategories: Freedom of Expression and } \\
\text { Belief, Associational and Organizational } \\
\text { Rights, Rule of Law, and Personal Autonomy } \\
\text { and Individual Rights. It ranges from } 1 \text { to } \\
7 \text {, with } 1 \text { representing the highest degree of } \\
\text { freedom or democratic rights and liberties and } \\
7 \text { the lowest. }\end{array}$ & $\begin{array}{l}\text { Freedom in the World } \\
\text { database }\end{array}$ \\
\hline $\begin{array}{l}\text { Political Rights } \\
\text { (POLRIGHTS) }\end{array}$ & $\begin{array}{l}\text { The political rights' rating includes three } \\
\text { subcategories: Electoral Process, Political } \\
\text { Pluralism and Participation, and Functioning } \\
\text { of Government. It ranges from } 1 \text { to } 7 \text {, with } 1 \\
\text { representing the highest degree of freedom } \\
\text { or democratic rights and liberties and } 7 \text { the } \\
\text { lowest. }\end{array}$ & $\begin{array}{l}\text { Freedom in the World } \\
\text { database }\end{array}$ \\
\hline STATUS & $\begin{array}{l}\text { The dummy variable STATUS is given the } \\
\text { value } 1 \text { when denoting countries which are } \\
\text { classified as partly free or not free, and } 0 \\
\text { otherwise (free countries). }\end{array}$ & $\begin{array}{l}\text { Author's calculations } \\
\text { based on the data of } \\
\text { Freedom in the World } \\
\text { database }\end{array}$ \\
\hline \begin{tabular}{|l|} 
CENTRAL \\
PLANNING
\end{tabular} & The number of years under central planning & \\
\hline NON-EU & $\begin{array}{l}\text { The dummy variable NON-EU is given the } \\
\text { value } 1 \text { if a country is not a member of the EU } \\
\text { and } 0 \text { otherwise. }\end{array}$ & \\
\hline INS & $\begin{array}{l}\text { The variable INS is defined differently in each } \\
\text { model. It relates to overall institutional quality } \\
\text { index and separate governance indicators. All } \\
\text { estimates of these indicators range from }-2.5 \\
\text { to } 2.5 \text { (the higher the number, the higher the } \\
\text { quality of institutions). }\end{array}$ & $\begin{array}{l}\text { Author's calculations } \\
\text { based on the data of } \\
\text { World Bank Worldwide } \\
\text { Governance Indicators } \\
\text { project database }\end{array}$ \\
\hline $\begin{array}{l}\text { Overall institutional } \\
\text { quality index } \\
\text { (OWGI) }\end{array}$ & $\begin{array}{l}\text { A composite governance indicator which is } \\
\text { constructed by the PCA of the governance } \\
\text { indicators. }\end{array}$ & $\begin{array}{l}\text { Author's calculations } \\
\text { based on the data of } \\
\text { World Bank Worldwide } \\
\text { Governance Indicators } \\
\text { project database }\end{array}$ \\
\hline
\end{tabular}


Jelena Zvezdanović Lobanova et al. • Governance and civil and political rights as FDI...

\begin{tabular}{|c|c|c|}
\hline Variables & Definition & Source \\
\hline $\begin{array}{l}\text { Control of Corruption } \\
\text { (CC) }\end{array}$ & $\begin{array}{l}\text { This variable captures the perceptions of the } \\
\text { extent to which public power is exercised for } \\
\text { private gain, including both petty and grand } \\
\text { forms of corruption, as well as "capture" of } \\
\text { the state by elites and private interests. }\end{array}$ & $\begin{array}{l}\text { World Bank Worldwide } \\
\text { Governance Indicators } \\
\text { project database }\end{array}$ \\
\hline Rule of Law (RL) & $\begin{array}{l}\text { This variable captures the perceptions of the } \\
\text { extent to which agents have confidence in and } \\
\text { abide by the rules of society, and in particular } \\
\text { the quality of contract enforcement, property } \\
\text { rights, the police, and the courts, as well as the } \\
\text { likelihood of crime and violence. }\end{array}$ & $\begin{array}{l}\text { World Bank Worldwide } \\
\text { Governance Indicators } \\
\text { project database }\end{array}$ \\
\hline $\begin{array}{l}\text { Regulatory Quality } \\
\text { (RQ) }\end{array}$ & $\begin{array}{l}\text { This variable captures the perceptions of the } \\
\text { ability of the government to formulate and } \\
\text { implement sound policies and regulations } \\
\text { that permit and promote private sector } \\
\text { development. }\end{array}$ & $\begin{array}{l}\text { World Bank Worldwide } \\
\text { Governance Indicators } \\
\text { project database }\end{array}$ \\
\hline $\begin{array}{l}\text { Political Stability and } \\
\text { Absence of Violence } \\
\text { (PSAV) }\end{array}$ & $\begin{array}{l}\text { This variable captures the perceptions of } \\
\text { the likelihood that the government will be } \\
\text { destabilized or overthrown by unconstitutional } \\
\text { or violent means, including politically- } \\
\text { motivated violence and terrorism. }\end{array}$ & $\begin{array}{l}\text { World Bank Worldwide } \\
\text { Governance Indicators } \\
\text { project database }\end{array}$ \\
\hline $\begin{array}{l}\text { Voice and } \\
\text { Accountability } \\
\text { (VA) }\end{array}$ & $\begin{array}{l}\text { This variable captures the perceptions of the } \\
\text { extent to which a country's citizens are able } \\
\text { to participate in selecting their government, } \\
\text { as well as freedom of expression, freedom of } \\
\text { association, and a free media. }\end{array}$ & $\begin{array}{l}\text { World Bank Worldwide } \\
\text { Governance Indicators } \\
\text { project database }\end{array}$ \\
\hline $\begin{array}{l}\text { Government } \\
\text { Effectiveness (GE) }\end{array}$ & $\begin{array}{l}\text { This variable captures the perceptions of } \\
\text { the quality of public services, the quality } \\
\text { of the civil service and the degree of its } \\
\text { independence from political pressures, } \\
\text { the quality of policy formulation and } \\
\text { implementation, and the credibility of the } \\
\text { government's commitment to such policies. }\end{array}$ & $\begin{array}{l}\text { World Bank Worldwide } \\
\text { Governance Indicators } \\
\text { project database }\end{array}$ \\
\hline
\end{tabular}

